\title{
Metaphor Construction in Caci Performance of Manggarai Speech Community
}

\author{
Karolus Budiman Jama \\ Universitas Nusa Cendana, Kupang, Indonesia \\ I Wayan Ardika \\ Universitas Udayana, Denpasar, Indonesia \\ I Ketut Ardhana \\ Universitas Udayana, Denpasar, Indonesia \\ I Ketut Setiawan \\ Universitas Udayana, Denpasar, Indonesia \\ Sebastianus Menggo \\ Universitas Katolik Indonesia Santu Paulus, Ruteng, Indonesia
}

\begin{abstract}
The construction of metaphoric expressions has awesome power in organising flexible performance aesthetics. It provides new angles on values of cultural rituals, encourages interlocutors' psychological functions in producing appropriate figurative languages, utilises awareness of all forms of linguistic and nonlinguistic knowledge, and increases the awareness of a community's values, belief systems, ideologies, and culture intertwined in speakers' minds. The aims of this study were to analyse and disclose the metaphor constructions in caci performance. The study was conducted between February and October 2018 and involved 24 caci actors from six villages in the Manggarai region, East Nusa Tenggara province, Indonesia. Interviews, a set of stationery, field notes, and audio-visual recordings were used to collect data. These data were then analysed qualitatively through the phenomenological method. The findings revealed that caci performance is thick with metaphor usage, such as animal, plant, physical, and water metaphors, and these were used in three stages of caci performance. Two ideologies underline caci performance, namely pragmatism and indoctrism. Caci actors are advised to employ metaphoric expressions to help them think and act, to reflect on living in harmony, and to deliver cultural values to the younger generation appropriately.
\end{abstract}

Index Terms - Caci performance, cultural communication, ideology, metaphor construction

\section{INTRODUCTION}

The art of language use or poetry is an art that appears mainly in the aesthetic spaces of caci performance in the culture of the Manggarai speech community. The Manggarai are one of the ethnic groups in western Flores, East Nusa Tenggara province, east Indonesia. They have diverse rituals which offer fundamental cultural values. The dictions used are strongly associated with metaphors and rhymes as an aesthetic feature. Metaphors have been found in all sorts of cultural rituals in this community such as caci performance, marriage proposal, mortality, naming of a newborn, opening new land, customary law, harvest ritual, and many more. Metaphor construction from a caci performance perspective is an awesome tactic in arousing the enthusiasm of caci doers and viewers. These metaphors begin to appear with custom ceremony planning, communicating to the invited village as the opponent of caci, opening ritual, welcoming the opponent of caci, caci performance as an aesthetic climax, and closing ritual.

The metaphor constructions are closely related to the customary rituals performed. The most fundamental values in a culture are coherent with the metaphorical structure of the most fundamental concepts in the culture (Menggo, 2018). The metaphors delivered have an important role in transferring messages and stimulating the emotions of the caci viewers. The art of language contains awesome power in organising the flexibility of the caci performance aesthetics. The power of language art, through metaphor, imprisons the psychology area of caci opponents and viewers. This aesthetic power in terms of permissive function is accepted as a fact without being rejected.

Communicating through metaphorical language implies the language role and diction are communication strengths. This is in line with Habermas's notion (Suseno, 2005, pp. 162-163). Habermas affirmed that language must become the centre of attention. Life is strongly determined by communication; this is called the institutional frame of a social system. This frame regulates interaction through the language function to guide oneself to be a meaningful communicator. Habermas's concept has been strengthened by research conducted by Menggo, Suastra, Budiarsa, and Padmadewi (2019), who claimed that knowledge of language function is believed to be a strong basis for a 
communicator to achieve his/her communication ability. Habermas believed that humans cannot avoid the knowledge of language function in supporting the achievement of communication aims that have been adhered to all mankind's life. Habermas's statement strengthens the role of metaphorical language practice in caci performance. This practice involves rational competence so that speakers grasp each other's intentions. But on the other side, metaphorical language practice is used to hegemonize interlocutors and caci doers, and hegemonize the viewers who are implicitly stated through ideology.

Hegemony is a theory that engages the meaning in each culture everywhere, in distributing the authority principle to dominate another. It is also a process to make, tend, maintain, and produce a set of meanings, as well as an ideology and authoritative practice (Barker, 2014, p. 119). The construction of metaphorical language is one of the authoritative assertion forms in hegemonizing. Language develops in the public space as an advertisement in propaganda language. On one side, the construction of metaphorical language is an aesthetic manifestation, but on the other side, it is manipulative space because it plays in the socio-psychology area. This area elicits the unconsciousness of the interlocutor of the utterance who agrees to accept. The essential metaphor construction also becomes a matter in philosophy. Language is key to solving philosophical issues and metaphor is the centre of the discussion (Sugiharto, 1999, pp. 79-80).

The construction of metaphor in caci performance affirms the existence of the artist. The appearance of an artist in caci performance is inspired by the experience of perusing the natural environment and socio-culture of Manggarai people. The inspiration of the artist aesthetic is based on values and ideology that are precipitated in the real life of the Manggarai.

Previous research presents convincing evidence that metaphorical language construction is a rhetorical ornament in helping speakers to think and act appropriately and deliver cultural values; as well it can be used as a creative strategy to cool down circumstances (Kolar, 2012; Menggo, 2018). However, the metaphor construction concept and cultural metaphors analysis, as well as the ideology implied in the cultural rituals of metaphors used, have not been strongly supported by recent research findings.

Cultural analysis of metaphors is an essential part of the current study. Metaphorical language is viewed as a great way to capture all emotions and ambiguous situations, stimulate the creative process, and use one's imagination to evoke and suggest new ways of speaking. It is the instrument to persuade, simplify, and attract the sympathy and empathy of the interlocutors as well (Cacciaguidi-Fahy \& Cunningham, 2007; Ivanovic, 2017). This paper synthesises all aspects regarding the concept of metaphor construction, cultural metaphor analysis, and the ideology implied in promoting valuable cultural communication.

Some studies have provided evidence that metaphorical language construction can provide a new point of view about the values of cultural rituals, stimulate interlocutors' psychological function in producing appropriate metaphoric expressions, and help apply all forms of linguistic and non-linguistic knowledge. For example, Chun and Yu (2008) claimed that the construction of metaphorical language is a persuasive way to express the deepest core values in the culture's rituals. They believe that metaphorical language expresses social construction in the form of the hierarchical and status symbols of one particular culture. Almirabi (2015) reported that metaphor construction can strengthen human relationships in multicultural backgrounds. According to her, metaphors produced have to be in line with interlocutors' cultural background, personality, thinking modes, and feelings, as well as geographic environments. Metaphor construction is a catalyst for generating new insights and multiple metaphors viewed as an expression of language creativity. Therefore, metaphorical language is necessary to avoid precarious assumptions based on vivid cognitive connections among speakers. Metaphor is constructed by using a wide range of concepts from science, literature, history, and an almost endless source of analogy (Meyer, Schwartz, College, \& Rochelle, 2008).

According to MacDonald, Baguley, and Kerby (2017), metaphor construction, as a tool to navigate diverse perspectives of experience, greatly enriches meaning-making by allowing speakers to contemplate, corroborate, and collaborate on appropriate ideas. The authors underlined that metaphor appears in collaborative practice to make meaningful connections between artists and one's practical life. It helps speakers expand their problem-solving capacities and allows them to cultivate authentic interaction. Metaphors are conscious attempts to situate speakers' knowledge in the appropriate communication context. Hence, metaphors must be considered as a text constituting elements of the community's values, belief systems, ideologies, and culture intertwined in speakers' minds (Dimas, 2018).

Referring to the above, it is obvious that there is a need for the current research, which differs from and expands upon previous studies by comparing the results of metaphor construction in the caci performance of Manggarai people in east Indonesia.

The purpose of this study is to analyse and disclose the metaphor constructions in caci performance. To achieve this, we formulated these research questions: (1) how do Manggarai people construct metaphorical languages in caci performance?, (2) what types of metaphors are relevant to the caci performance of Manggarai people?, (3) what ideologies are implied in the metaphors used in the caci performance of Manggarai people?

\section{REVIEW OF LITERATURE}




\section{A. Caci Performance}

The Manggarai ethnic group in the eastern part of Indonesia possesses a unique traditional art, which is called caci. In etymology understanding, caci emanates from the term $\mathrm{ca}$ meaning one and $c i$ meaning test. Referring to the onomatopoeia, caci originates from the soft, rhythmic screeches cacaca...cicici from men's mouths who demonstrate caci. This definition is meaningful. Caci is the art of testing ability and Manggarai's agility in the kinaesthetic and aesthetic domains. Kinaesthetic ability became related to the agility of striking and rebutting. Meanwhile, caci aesthetic concerns art in its performance practice. Caci performance is done by two men from two village groups that have kinship relationships voluntarily whipping each other.

$\mathrm{Caci}$ is performed for cultural ritual interests such as penti (the celebration of a custom's anniversary, which is related to the agricultural work season); wagal (marriage), carried out if a man's family ('outsider') fulfils all affairs of the dowry; Independence Day celebration of the Republic of Indonesia; congko lokap (the inauguration of a traditional house), performed before or after the peak of sacrificial buffalo animal rituals; lingko randang (botanical garden party), done for agricultural fertility and legitimacy toward arable land; and rowa/kélas (the peak of the celebration of death). This last caci type is particularly for the Rongga ethnic group, one of the ethnic groups in the Manggarai speech community (Beeh, 2017).

As an art form, caci integrates several art elements in one performance such as music, dance, costume, theatre, and metaphor construction aesthetics, and these are interrelated (Sawaludin \& Salahudin, 2016). Consequently, caci doers are used to mastering the art elements in the caci show. Hatley et al. (2014, p. 3) disclosed that art performance possesses a strategic position in the life of Indonesian society. According to the authors, art performance is done to show power, strengthen social relations, and celebrate values believed and held in common. Besides that, art performance is also used as a space to criticise social and political problems.

Caci performance for Manggarai people is an art that fastens, becomes an identity, and offers shared values as well. This art is performed to legitimise a custom event and purification space, and, conversely, to transition space from the sacred to the routine.

\section{B. Definition and Usage of Metaphor}

Metaphor leads to rules of logic and knows the root of logic from a cultural group. Metaphor is the fundamental character of human linguistic relations with the world (Sugaharto, 1999, p. 102). Sugaharto added that metaphor is giving a name that belongs to something else, transference from genus to species or by analogy. This is in line with the concept of metaphor proposed by St Clair (2004), who defined metaphorical expressions as statements based on some kind of analogy where two things are compared to each other. Lakoff and Johnson (1980) said that metaphor is an expression of imaginative and language creativity and it can be seen in everyday life, in thought, language, and action (p.7). They provide the example of time is money, which is reflected in our daily activities.

Metaphor languages are used in everyday language and play a role in all areas of life. There is no exception in the therapeutic domain. Therefore, metaphor is not just a matter of language but also a speaker's cognitive process. Witztum, der Hart, and Friedman (1988) reported that metaphor utterances are used in everyday life and play a role in all segments of life, including in the therapeutic domain. They believe that metaphoric expressions are a therapeutic technique for clinicians to cure patients. Metaphor usage cannot be avoided in speakers' experiences of life. Lusekelo and Kapufi (2014) pointed out that it is about sharing experiences of the world in terms of socio-cultural materials, beliefs, and values from which the metaphors originate amongst speakers. They use metaphoric expressions to ensure everyone (encoders and decoders) feels affirmed in social interaction.

Ivanovic (2017) highlighted that metaphors are usually derived from common source domains that can be found in all languages and cultures. Often, metaphoric expressions are retrieved from such source domains as a human body, fertility, animals, plants, economics, religion, and many more. Moreover, metaphor is used to analogise external objects close to human life such as jungles, deserts, islands, tundra, mountains, cities (Lakoff \& Johnson, 1980, p. 146).

\section{Metaphor and Ideology}

Generally, ideology is a way of looking at the world in a cultural group. Through ideology, every cultural group constructs and establishes its life. Barker (2014, p. 137) explained ideology as ideas, group meaning, practice in regulating the procedures for practical and moral behaviour. Ideology has an important role in constructing metaphorical expressions. It is a substratum for speakers to produce metaphorical languages appropriately. By referencing the right ideology, the speaker accustoms himself/herself and others in socio-historical and socio-cultural contexts to achieve meaningful communication. Moreover, ideology is a set of notions that guides human groups in behaving toward certain goals, and ideology is used for human liberation (Takwin, 2009, p. 5).

\section{METHODS}

\section{Approach and Method}

This research used a qualitative approach with a phenomenological method. The qualitative approach intended to know the natural setting to interpret phenomena and involve various existing methods (Satori \& Komariah, 2010, p. 23). A phenomenological research method is used in this research, closely interpreting individuals' experiences. This is 
intended to understand the meaning of experience from the perspective of the participant (Emzir, 2010, p. 22). This research was conducted from February to October 2018 and involved 24 caci actors from six villages in the Manggarai region, western Flores, East Nusa Tenggara province, East Indonesia.

\section{Informant}

The informants of the research were 24 persons, all native speakers of Manggarai language and caci artists. They are also customary leaders experienced in constructing metaphors in the caci performance. The 24 persons were selected as informants by using purposive sampling and snowball techniques.

\section{Instruments}

Based on research characteristics, the primary instrument of this research was the researchers themselves. This is in line with the notion proposed by Lincon and Guba (Satori \& Komariah, 2010) who affirmed that humans can be data collector instruments because they are flexible and adaptive by using all their senses. Then, this primary instrument was assisted by secondary instruments such as interviews, a set of stationery, field notes, and audio-visual recordings. All the questions in the interview were researcher-made and then checked by five experts for relevance and content validity before being given to respondents. The five experts were from Udayana University, Denpasar, Indonesia.

\section{Method of Data Analysis}

After the data were collected, the next step was to conduct data analysis. The method used in this research was qualitative data analysis through the phenomenological method. First, we made a list and grouped the metaphors that had been collected. Second, we reduced and eliminated the metaphor data. Third, we grouped and gave an ideological theme to each metaphor construction. Fourth, we identified the final data. After all the data were collected and grouped, they were described and analysed based on the theory used.

\section{Procedure of Data Analysis}

Analysis of the data in this study was through the procedure of form and meaning. Every cultural phenomenon has a form, then the form has its function which ultimately has a certain meaning (Ratna, 2016, p. 345). The obtained metaphors are viewed from the form based on classification. From that we could see the function in metaphorical construction. The next step was to carry out an analysis to get the meaning or ideology behind it. Informants were divided into six groups and were seated in a face-to-face seating arrangement. The researchers proposed each question from the interview list and then all of them could freely answer according to what they have experienced and knew about the metaphor construction in caci performance. Informants voluntarily responded to the questions given.

\section{Ethical Code of Research}

This research has obeyed rules and regulations for researching in Indonesia. It has been approved by the research boards from three regencies in Manggarai region, western Flores, East Nusa Tenggara province, eastern part of Indonesia. This research was also sponsored by the Indonesia Endowment Fund for Education (LPDP).

\section{FINDINGS}

Referring to the research problems, there are three research findings related to the metaphor construction of Manggarai ethnic in caci performance. First, metaphor constructions are used in caci performance spaces such as invite caci opponent, ritual space, welcoming and performance of caci. Second, metaphor types in caci performance are animal metaphors, plants, body or physical, and water metaphors. Third, the ideologies behind these metaphors are commonly about economy ideology, identity, and moral ideology. These ideologies mentioned are shaded by two prime ideologies, namely pragmatism and indoctrism. 
TABLE 1

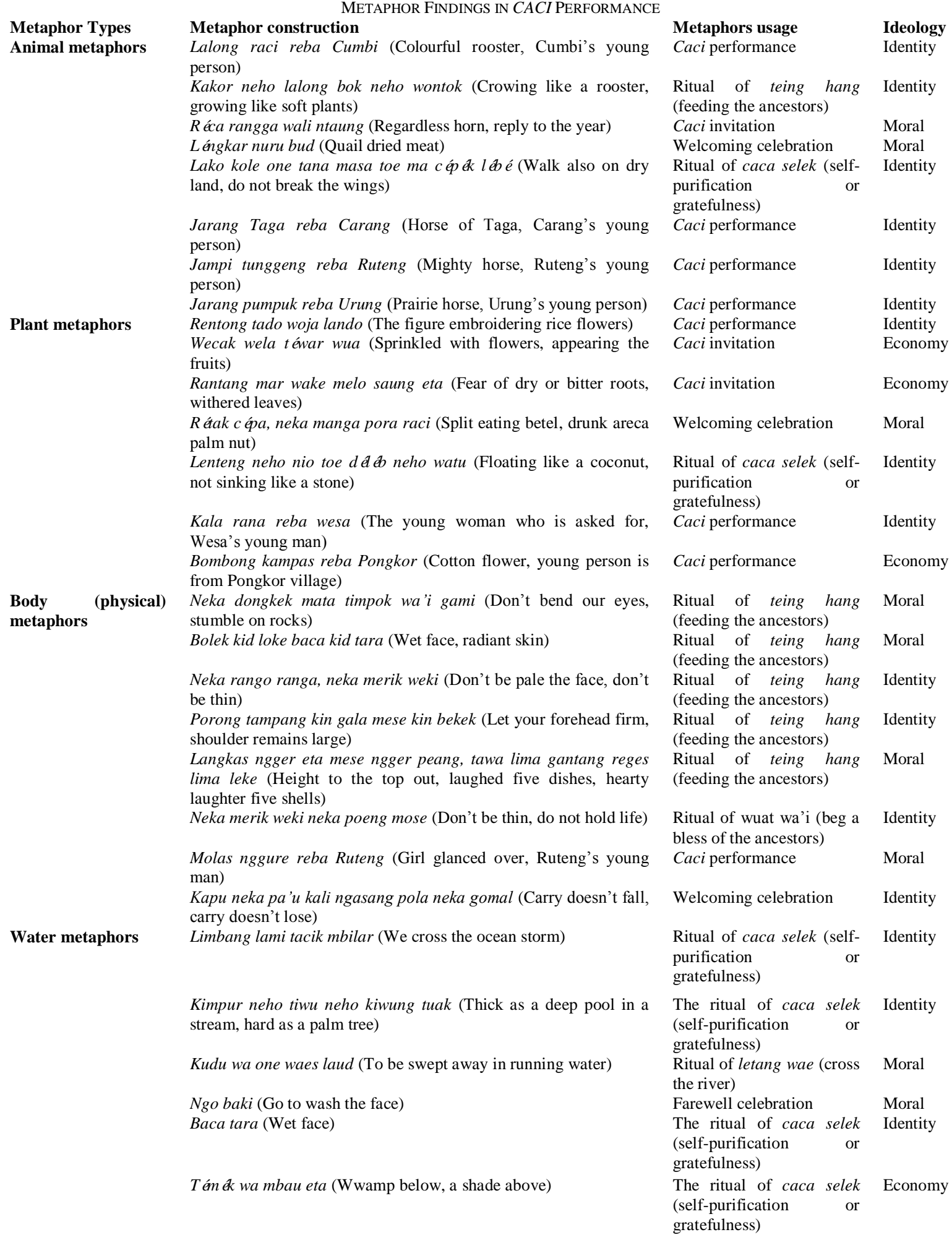

The data obtained from the caci performance indicated some valuable findings to be considered. Based on the findings of the metaphors in caci performance (table 1), 24 caci actors constructed four types of metaphors: animals, plants, body, and water metaphors. Four metaphors were employed in different stages of caci performance with the three ideologies behind them.

\section{DISCUSSION}

Caci performance consists of several important interconnected aesthetic spaces. These aesthetic spaces cannot be separated from one another. First, caci performance is used to possess the opponent, which is called meka landang 
(outsiders). Meka landang are invited and indicated by giving them tuak (local palm wine). Second, caci performance is preceded by doing the traditional ritual, to feed the ancestors (ritual offerings to spirits) as a philosophy of caci itself. There are three stages in doing the ritual space for feeding the ancestors — namely, pre-departure day, which is done at night; wuat wa' $i$ ritual (beg a blessing of the ancestors), done on departure day and in the morning; and the ritual of caca selek (self-purification or gratefulness), done after caci performance. Third, welcoming toward meka landang is done at the village gate. Fourth, a welcoming celebration is held in the mbaru gendang (traditional house in a village). Fifth, the caci episode is the peak of caci performance, done in the village square. Sixth, farewell is the final caci episode. Seventh, the ritual of caca selek is a sign of the end of the whole series of caci performances.

The rite of welcoming the guest, as carried out at caci performances above, plays an important role in the cultural communication of Manggarai people. Ndiung and Bayu (2019) reported that people in Manggarai have a unique tradition in the procedure of welcoming the guest that plays an important role in solidifying brotherhood and fostering hospitality. They further describe that the procedure of welcoming the guest in the Manggaraian tradition is called tiba meka (welcoming guest) rite. The guests welcomed with this rite are commonly outsiders, government figures, public figures, and religious leaders.

Caci aesthetic spaces are filled with dialogue texts, performing the beauty of language in the form of metaphors. There are several metaphor groups that are constructed in each caci aesthetic space. The types of those metaphors consist of plant, animal, body or physical, and water metaphors. These metaphors are used based on moral, identity, and economy ideology. Ideology affects the insight of caci doers in constructing the relevant and appropriate utterances. Sawaludin and Salahudin (2016) claimed that there are some philosophical values within caci performance, and the Manggarai people have preserved this tradition. They further reveal that philosophical values that appear within caci performance are aesthetic in constructing metaphor, bravery, tolerance, brotherhood, togetherness, politeness, sportsmanship, willingness to sacrifice, responsibility, peacefulness, and those able to live in harmony in this speech community. In line with the living in harmony concept, Solikhah (2016) found that the metaphor constructions have to represent our respect for living in harmony with human beings, nature, ancestors, and God. The metaphor expressions stimulate the reflection of how people are able to keep harmony and peacefulness in the community.

Metaphor construction at the time of inviting meka landang (outsiders) is uttered in the following short excerpt, rantang mar wake melo saung eta. This short excerpt literally means 'fear of dry roots under dry leaves above'. In this metaphor, humans are analogised with plants. Humans are equated with plants so that human life is not easy to dry and wither like plants. This metaphor realises that humans are vulnerable to conditions like plants, as well as the expectation toward the fertility of crops. This is in line with the metaphor construction nenggitu kole po'ong agu paeng lime pande dami 'likewise with work in our garden'. These two metaphor constructions have an emphasis on the ideological meaning behind them. The ideology background of these metaphor utterances is the economy. As a speaker in delivering these utterances, the expectation for fertility and welfare is implicitly stated. Economy ideology contributes to the way of thinking in constructing metaphorical expressions. McKinnon (2013) found that metaphor construction is premised on a strong ideology so that it is useful and profitable for the speech community.

Metaphor reality aesthetic comes to the space of feeding the ancestors one day before leaving for the caci performance by the invited side, that is, meka landang (outsiders/opposing side). In this ritual, all of caci doers assemble at the traditional house for the ritual undertaking. The ritual is led by an old man. The typical metaphor in this ritual is the metaphor for protection. Physical metaphor is one of the metaphors that is often spoken in the ritual speech of feeding the ancestors. The metaphor of bolek kid loke baca kid tara (wet face, radiant skin) is associated with a moral ideology. The point is the simplicity of a caci actor. A caci actor has moral responsibility in performing the grace of caci. The caci actor performs the grace, expresses the peace, and provides a sense of being calm for all the audience present as far as possible, especially for the families left behind when playing caci performances.

The metaphor above-mentioned is a moral perspective on the Manggarai ethnic group. Providing a sense of comfort is characteristic of the Manggarai people, who avoid giving offence to prevent conflict as much as possible. Moral ideology is an instrument for preventing conflict, judging and reasoning, self-justification, knowing how our thoughts or ideas are formulated and then directing them to produce the appropriate utterances (Freeden, 2006). Similarly, Sua, Anshari, and Maman (2017) reported that moral value utterances are an instrument to aid people in daily life interaction. According to them, moral value utterances reflect people in Bone, Indonesia to be humble, gentle, honest, and polite toward each other.

The next metaphor in the ritual of feeding the ancestors is neka rango ranga, neka merik weki, porong tampang kin gala mese kin bekek (don't be pale the face, don't be small, let your forehead firm, shoulder remains large). This metaphor is based on the ideology of identity. Each group of caci actors shows the others the ability and maintains the dignity of the caci actor and his village. Identity ideology is related to the injury suffered by the caci actor when the men in the scene whip each other. The strength and agility of the caci actors become a target point in the ideology of identity. Physical endurance and agility in fending off the opponent's strike are important things for a caci actor to possess. The identity battle is thick in the caci scene. A facial injury suffered by a caci actor is jointly felt by all members of his group, because facial injury is a joint responsibility for all village groups. This is the identity of the injured village and becomes the subject of discussion. That is the importance of maintaining the identity of the caci actor to maintain the mutual identity in the community. 
Another metaphor present in the ritual is wuat wa'i (beg a blessing of the ancestors). This ritual aims to strengthen the spirit and physique of the caci actors in each other to fight. Neka merik weki neka koeng mose (don't be small, don't be low on dignity) is one example of physique, a metaphor when the wuat wa' $i$ ritual is done. That metaphor has the meaning of physical strength and mental endurance in the caci performance. This metaphor is in contact with the ideology of identity. Vengadasamy (2011) reported that metaphors are ideological constructs for a group identity. As a consequence, metaphor constructions have to provide an insight into strengthening one's cultural heritage and being assimilated into the society of the adopted country.

The ritual of letang wae (cross the river) is a ritual to discard and ward off bad things toward the whole caci group. This ritual is carried out in a river flow that limits the territory of the two villages that will do the caci performance. In this ritual, the characteristic metaphor is the water metaphor - for example kudu wa one waes laud (all bad things washed away with running water). The ideology that underlines this is the moral ideology. Water is a symbol of the purification and life of the Manggarai people. Because of that, the water metaphor always appears in the discussion related to bad things, especially about physical purification and soul safety. Based on this ideology, the Manggarai ethnic group needs to take care of an attitude of life toward others and nature.

The moral ideology entity in the caci performance is indicated when performing a welcoming ritual for meka landang (outsider). Kapu neka pa'u kali ngasang pola neka gomal (respect as the identity of the village organiser) is an example of a metaphor in the welcoming ceremony with the ideology of identity background. Through this ideology, the organiser shows their respect to the outsider. Kindness is an identity that must be addressed by the organiser. Therefore, the organiser as much as possible serves the guests (outsiders), especially in terms of consumption. This is related to the sense of comfort for both the organiser and the guests of caci. Food and drink for the guests of caci should not be lacking.

The climax of caci performance lies in the mutual flogging scene. Caci actors in the mutual flogging scene produce metaphoric expressions. The metaphors that mainly appear in the mutual flogging scene are animal and plant metaphors. One of the animal metaphors produced by caci actors is lalong raci reba Cumbi (colorful rooster, a young person is from Cumbi village). The ideology carried in this metaphor is the ideology of identity. The caci actor likens himself to a beautiful rooster that is agile and skilful. This relates to the role of chicken as a time marker, signalling danger and natural signs of the Manggaraian ethnic group. Bombong kampas reba Pongkor (cotton flower, a young person is from Pongkor village) is one of the plant metaphors that presents together with the ideology of the economy. The caci actor in this metaphor proclaims the importance of economic power in supporting life. The economy is likened to the cotton billow that encourages the life of the Manggarai to become more peaceful. The aims are happiness and welfare.

The water metaphor is performed when the caci guests undertake the farewell agenda to the organiser. Ngo baki (go to wash the face) is a metaphor that functions permissively. This metaphor is used in the argumentation for getting permission from the organiser. The ideology that underlines this metaphor is moral ideology. This ideological basis is conveyed in the metaphor as a refinement and form of appreciation for the organiser. In terms of moral ideology, the Manggarai do not want any offence in building social relations and more aesthetics.

The last space in the caci performance is the ritual of caca selek (self-purification or gratefulness). Several metaphors are conveyed in this space such as (1) water metaphor limbang lami tacik mbilar (we cross the ocean storm); (2) plant metaphor lenteng neho nio toe déléb neho watu (floating like a coconut, not sinking like a stone); (3) animal metaphor kako kole one tana masa toe ma cépék lébé (walk also on dry land do not break the wings). The metaphors are based on the ideology of identity with the caci guest group, a metaphor that conveys excellence and success in caci performance. Therefore, it is important to do the ritual of caca selek as an expression of gratitude and especially put the ancestral spirits back in place and the soul back in the body.

\section{CONCLUSION}

Caci performance in the Manggarai ethnic group of east Indonesia is thick with metaphors, which are constructed based on ideological backgrounds. These metaphors consist of animal, plant, physical, and water metaphors. The metaphors are used in three stages of performance, namely (1) pre-performance (welcoming caci opponent), done at the organiser's village gate, (2) whilst-performance stage, done in the village square, and (3) post-performance stage (farewell), done in the organiser's traditional house.

The ideologies that underline the metaphor in caci performance are classified into two major ideologies: first, pragmatism ideology, the concept that regulates the order of everyday life of the Manggaraian people; second, indoctrism ideology, which is the indoctrination process that educates the philosophical concept and viewpoint of the life of Manggaraian people in building good relationships between humans, humans and nature, humans and spirit, and especially humans and God.

\section{ACKNOWLEDGMENTS}

The researchers would like to gratefully acknowledge the Indonesia Endowment Fund for Education (LPDP) Indonesia for their support and grant given in finishing this research. 


\section{REFERENCES}

[1] Almirabi, M. M. (2015). When metaphors cross cultures. Journal of Language Teaching and Research, 6(1), 204-209. http://dx.doi.org/10.17507/jltr.0601.25.

[2] Barker, C. (2014). Kamus kajian budaya. Yogyakarta: Kanisius.

[3] Beeh, Y. Y. (2017). The role of community in the development of Wae Rebo as a community-based tourism destination in East Nusa Tenggara. Journal of Business on Hospitality and Tourism, 3(1), 55-79.

[4] Cacciaguidi-Fahy, S. \& Cunningham, J. (2007). The use of strategic metaphors in intercultural business communication. Journal of Managing Global Transitions, 5(2), 133-155.

[5] Chun, J. \& Yu, F. (2008). Cultural metaphors in China: A visual experience of hierarchy and status symbols. Intercultural Communication Studies, 17(1), 71-78.

[6] Dimas, H. M. S. (2018). Teacher's situated knowledge through metaphor construction and its story- licensing. Lenguaje, 46(2), 292-310. https://doi.org/10.25100/lenguaje.v46i2.6584.

[7] Emzir. E. (2010). Metode penelitian kualitatif: Analisis data. Jakarta: Rajawali Press

[8] Freeden, M. (2006). Ideology and political theory. Journal of Political Ideologies, 11(1), 3 22.https://doi.org/10.1080/13569310500395834.

[9] Hatley et al., (2014). Seni pertunjukkan Indonesia: Pasca orde baru. Yogyakarta: Universitas Sanata Dharma.

[10] Ivanovic, I. (2017). Comparative study of metaphor in the British and United States of America (US) political discourse. XLinguae Journal, 10(2), 16-29. https://doi.org/10.18355/XL.2017.10.02.02.

[11] Kolar, T. (2012). Using metaphors as a tool for creative strategic sense-making. Journal of Economic and Business Review, 14(4), 275-297.

[12] Lakoff, G. \& Johnson, M. (1980). Metaphors we live by. Chicago: University of Chicago Press.

[13] Lusekelo, A. \& Kapufi, D. I. (2014). An analysis of metaphoric use of names of body parts in the Bantu language Kifipa. International Journal of Society, Culture \& Language, 2(1), 106-118.

[14] MacDonald, A. J., Baguley, M. M., \& Kerby, M. C. (2017). Collaboration as metaphoric construct and guiding practice in artmaking and teaching. Journal of Issues and Research, 58(4), 312-324. https://doi.org/10.1080/00393541.2017.1368290.

[15] McKinnon, A. M. (2013). Ideology and the market metaphor in rational choice theory of religion: A rhetorical critique of 'religious economies'. Critical Sociology, 39(4), 529-543. https://doi.org/10.1177/0896920511415431.

[16] Menggo, S. (2018). "Metaphors usage in the marriage proposal ritual in Manggarai, East Indonesia". Proceedings of the $1^{\text {st }}$ International Conference on Local Languages Held by Masters and Doctoral Programs of Linguistics Faculty of Arts, Udayana University, 709-714.

[17] Menggo, S., Suastra, I. M., Budiarsa, M., \& Padmadewi, N. N. (2019). Speaking for academic purposes course: An analysis of language functions. E-Journal of Linguistics, 13(2), 314-332. https://doi.org/10.24843/e-j1.2019.v13.i02.p10.

[18] Meyer, J. P., Schwartz, T., College, I., Rochelle, NY. (2008). The metaphor matrix: Improving metaphor usage in management education. The Journal of American Academy of Business, 3(2), 37-44.

[19] Ndiung, S. \& Bayu, G. W. (2019). Ritus tiba meka orang Manggarai dan relevansinya dengan nilai-nilai karakter. Jurnal Pendidikan Multikultural Indonesia, 2(2), 14-21.

[20] Ratna, K. N. (2016). Metodologi penelitian: Kajian budaya dan ilmu sosial humaniora pada umumnya. Yogyakarta: Pustaka Pelajar.

[21] Satori, D. \& Komariah, A. (2010). Metode penelitian kualitatif. Bandung: Alfabeta.

[22] Sawaludin, S. \& Salahudin, M. (2016). Nilai-nilai karakter bangsa dalam tradisi tari caci di masyarakat Manggarai Desa Golo Ndoal Kecamatan Mbeliling Kabupaten Manggarai Barat Nusa Tenggara Timur. Civicus Journal, 4(2), 59-64.

[23] Solikhah, I. (2016). Metaphors in Javanese mantra of Kiyai Pradah ritual ceremony. Indonesian Journal of Language Teaching and Linguistics, 1(2), 127-142.

[24] Sua. A. T., Anshari, A. \& Maman, M. (2017).The form, function, and value of Buginese utterances of Bone society. Journal of Language Teaching and Research, 8(5), 928-933. http://dx.doi.org/10.17507/jltr.0805.12.

[25] Sugiharto, B. (1999). Posmodernisme tantangan bagi filsafat. Yogyakarta: Kanisius.

[26] Suseno, F. M. (2005). Pijar-pijar filsafat. Yogyakarta: Kanisius.

[27] St. Clair, R. N. (2004). Visual metaphor, cultural knowledge, and the new rhetoric. In Jon Reyhner, et al. (Eds.), Learn in beauty: Indigenous education for a new century (Chp. 8). Flagstaff, AZ: Northern Arizona State University.

[28] Takwin, B. (2009). Akar-akar ideologi. Yogyakarta: Jalasutra.

[29] Vengadasamy, R. (2011). Metaphors as ideological constructs for identity in Malaysian short stories. The Southeast Asian Journal of English Language Studies, 17(Special Issue), 99 - 107.

[30] Witztum, E., Derhart, O. V. \& Friedman, B. (1988). The use of metaphors in psychotherapy. Journal of Contemporary Psychotherapy, 18(4), 270-276.

Karolus Budiman Jama was born in Manggarai, Indonesia. He is a lecturer in Indonesian Language and Literature Education Department at Universitas Nusa Cendana, Kupang, Indonesia. He obtained his Master Degree in Art Education in 2013 from Universitas Pendidikan Indonesia, Bandung, Indonesia. He is currently a doctorate candidate in Cultural Studies at Universitas Udayana and his main research is focused on Culture and Art Studies.

I Wayan Ardika is a Professor in Archeology Department at Universitas Udayana, Denpasar, Indonesia. He received his Master in Prehistory from Australian National University in 1987 and his Doctorate in Prehistory at Australian National University in 1992. 
His research interests include a wide range of topics related to Archeology and Cultural Studies. He has supervised many theses and doctorate dissertations. He has participated in numerous national and international conferences and has written a lot of articles.

I Ketut Ardhana is a Professor in Historical Study Department at Universitas Udayana, Denpasar, Indonesia. He received his Master in Southeast Asian Studies from Australian National University, Australia in 1994 and his Doctorate in Philosophy from Passau University, Germany in 2000. His research interests include a wide range of topics related to Historical and cultural Studies. He has supervised many theses and doctorate dissertations. He has participated in several national and international conferences and has written a lot of articles.

I Ketut Setiawan is a Doctor in Cultural Studies and Head of Archeology Department at Universitas Udayana, Denpasar, Indonesia. He received his Master in Archeology from Universitas Indonesia in 1995 and his Doctorate in Cultural Studies from Universitas Udayana, Denpasar, Indonesia in 2011. His research interests include a wide range of topics related to Epigraphy, Culture, and Tourism Studies. He has supervised many theses and doctorate dissertations. He has published many articles and books and actively participated in national and international conferences and academic workshops.

Sebastianus Menggo is a Doctor in English Department at Universitas Katolik Indonesia Santu Paulus, Ruteng, Indonesia. He obtained his Master Degree in English Education in 2013 from Universitas Pendidikan Ganesha, Singaraja, Indonesia, and his Doctorate in Applied Linguistics from Universitas Udayana, Denpasar, Indonesia. His research interests include a wide range of topics related to linguistics and culture. He has published many international journal articles and books and actively participated in national and international conferences and academic workshops. 